\title{
Purification and Properties of Extracellular Lipases with Transesterification Activity and 1,3-Regioselectivity from Rhizomucor miehei and Rhizopus oryzae
}

\author{
Miklós Takó $^{1 *}$, Alexandra Kotogán ${ }^{1}$, Tamás Papp ${ }^{1,2}$, Shine Kadaikunnan ${ }^{3}$, Naiyf S. Alharbi ${ }^{3}$, and Csaba Vágvölgyi ${ }^{1}$ \\ ${ }^{1}$ Department of Microbiology, Faculty of Science and Informatics, University of Szeged, H-6726 Szeged, Közép fasor 52, Hungary \\ ${ }^{2}$ HAS-USZ "Momentum" Fungal Pathogenicity Mechanisms Research Group, University of Szeged, H-6726 Szeged, Közép fasor 52, Hungary \\ ${ }^{3}$ Department of Botany and Microbiology, College of Science, King Saud University, Riyadh-11451, Saudi Arabia
}

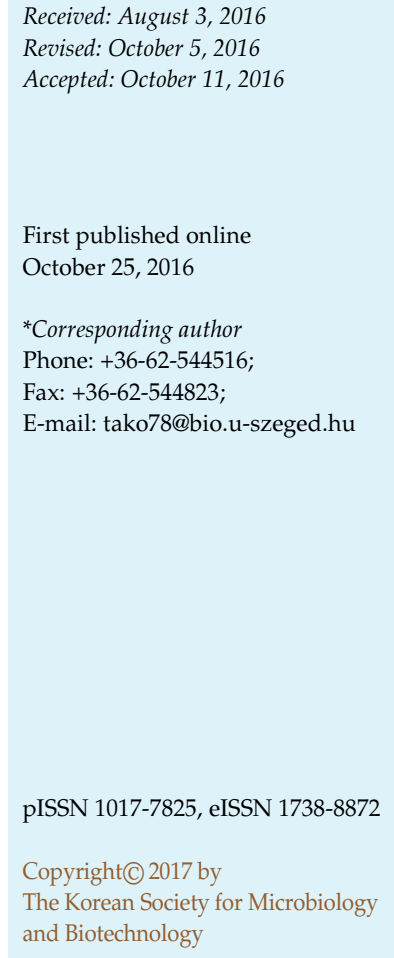

Rhizomucor miehei NRRL 5282 and Rhizopus oryzae NRRL 1526 can produce lipases with high synthetic activities in wheat bran-based solid-state culture. In this study, the purification and biochemical characterization of the lipolytic activities of these lipases are presented. SDSPAGE indicated a molecular mass of about 55 and $35 \mathrm{kDa}$ for the purified $R$. miehei and $R h$. oryzae enzymes, respectively. $p$-Nitrophenyl palmitate $(p \mathrm{NPP})$ hydrolysis was maximal at $40^{\circ} \mathrm{C}$ and $\mathrm{pH} 7.0$ for the $R$. miehei lipase, and at $30^{\circ} \mathrm{C}$ and $\mathrm{pH} 5.2$ for the $R h$. oryzae enzyme. The enzymes showed almost equal affinity to $p \mathrm{NPP}$, but the $V_{\max }$ of the $R h$. oryzae lipase was about 1.13 times higher than that determined for $R$. miehei using the same substrate. For both enzymes, a dramatic loss of activity was observed in the presence of $5 \mathrm{mM} \mathrm{Hg}^{2+}, \mathrm{Zn}^{2+}$, or $\mathrm{Mn}^{2+}$, $10 \mathrm{mM} \mathrm{N}$-bromosuccinimide or sodium dodecyl sulfate, and $5-10 \%(\mathrm{v} / \mathrm{v})$ of hexanol or butanol. At the same time, they proved to be extraordinarily stable in the presence of $n$ hexane, cyclohexane, $n$-heptane, and isooctane. Moreover, isopentanol up to $10 \%(\mathrm{v} / \mathrm{v})$ and propionic acid in $1 \mathrm{mM}$ concentrations increased the $p \mathrm{NPP}$ hydrolyzing activity of $R$. miehei lipase. Both enzymes had 1,3-regioselectivity, and efficiently hydrolyzed $p$-nitrophenyl ( $p \mathrm{NP})$ esters with $\mathrm{C} 8-\mathrm{C} 16$ acids, exhibiting maximum activity towards $p$ NP-caprylate (R. miehei) and $p$ NP-dodecanoate (Rh. oryzae). The purified lipases are promising candidates for various biotechnological applications.

Keywords: Zygomycetes, extracellular lipase, enzyme purification, lipolysis characterization, synthetic activity

\section{Introduction}

Lipases (glycerol ester hydrolases; E.C. 3.1.1.3) find promising applications in a wide range of biotechnological and industrial processes, including flavor enhancement in the food industry, biodiesel production, and pharmaceutical processing [1, 2]. These enzymes hydrolyze the triacylglycerols to fatty acids, glycerol, and partial acylglycerols. This reaction is reversible; thus, lipases also catalyze the formation of acylglycerols from glycerol and free fatty acids via esterification. Other valuable properties of most lipases are the ability of catalyzing enzymatic interesterification reactions rearranging a triglyceride molecule, and transesterification between oil compounds, alkyl or aryl esters, and alcohols [3]. Lipases can also be used to accelerate the degradation of fatty waste and polyurethane $[4,5]$.

Many species of the fungal subphylum Mucoromycotina (a representative group of the former class Zygomycetes) have successfully been used in several areas of biotechnological applications, including biotransformation of steroid compounds, production of organic acids, and other valuable bioactive metabolites (e.g., carotenoids, polyunsaturated fatty acids), as well as production of extracellular enzymes [6]. Some strains, especially those 
belonging to the genera Mucor, Rhizomucor, and Rhizopus, are well known from a food-industrial point of view, in consequence of their effective enzyme production [7].

Industrial application of fungal lipases has spread out in the last decades, replacing the expensive and timeconsuming chemical processes [8]. Therefore, the need for new producer strains and enzymes with industrially useful properties has increased, and current research studies are mainly focused on enzymes potentially utilizable for catalysis of specific reactions, such as alkyl and phenyl ester synthesis. There are excellent lipase producers among Mucoromycotina fungi, and some enzymes have been isolated and characterized from this group $[9,10]$. The most frequently used isolates to obtain lipase preparations with outstanding practical interest are from Rhizomucor, Rhizopus, and Mucor species [7]. Some of these biocatalysts expose high synthetic activity and thus can be utilizable for production of eco-friendly biofuels [11].

In the frame of our recent study, the lipolytic activity of several Mucoromycotina strains was tested by liquid and solid-state fermentation methods. Some thermophilic Rhizomucor and Rhizopus isolates showed intensive extracellular lipase activity, and the enzyme production was maximal when wheat bran was used as the carbon source [12]. The transesterification capacity of their crude lipase extracts was investigated in non-aqueous conditions, in which the Rhizomucor miehei NRRL 5282 and Rhizopus oryzae NRRL 1526 enzymes efficiently catalyzed the formation of ethyl palmitate ester at $40^{\circ} \mathrm{C}$ [13].

The present study describes the isolation of the R. miehei NRRL 5282 and Rh. oryzae NRRL 1526 lipases and biochemical characterization of their hydrolytic activities, including temperature and $\mathrm{pH}$ optimum assays, stability studies in the presence of various solvents and metal salts, and examinations for their substrate specificity and regioselectivity. Transesterification activity of the purified lipases has also been identified.

\section{Materials and Methods}

\section{Solid-State Fermentation}

For the induction of lipase production, $10^{6}$ spores of $R$. miehei NRRL 5282 or Rh. oryzae NRRL 1526 were transferred to $3 \mathrm{~L}$ Erlenmeyer flasks containing $130 \mathrm{~g}$ of wheat bran moisturized with $130 \mathrm{ml}$ of mineral salt medium and $1.5 \%(\mathrm{w} / \mathrm{v})$ olive oil [12]. The cultures were incubated at $37^{\circ} \mathrm{C}$ for 6 days.

\section{Purification of the Enzymes}

The wheat bran-fungal mycelia ferment was extracted with $800 \mathrm{ml}$ of $100 \mathrm{mM}$ acetate buffer $(\mathrm{pH} 6.0)$ at $4^{\circ} \mathrm{C}$ for $24 \mathrm{~h}$. After filtration on gauze and Whatman No. 1 filter paper, the crude extract was centrifuged at 5,040 $\times g$ for $15 \mathrm{~min}$. The protein of the supernatant was precipitated by ammonium sulfate, and precipitates from the fractions of $50 \%$ to $85 \%$ saturation were collected by centrifugation $(5,040 \times g, 15 \mathrm{~min})$. Then, the concentrates were re-dissolved in the smallest possible volume of $100 \mathrm{mM}$ acetate buffer ( $\mathrm{pH}$ 6.0). Precipitates of the fractions having saturation between $50 \%$ and $65 \%$ (in the case of $R h$. oryzae) and $75 \%$ and $85 \%$ (in the case of R. miehei) showed the highest lipolytic activity. These concentrated enzyme solutions were loaded onto a Sephadex G-75 (Sigma-Aldrich, Germany; exclusion range 3 to $80 \mathrm{kDa})$ column $(16 \times 325 \mathrm{~mm})$ equilibrated with $50 \mathrm{mM}$ acetate buffer (pH 6.0). Elution was carried out at a flow rate of $0.5 \mathrm{ml} / \mathrm{min}$ using the same buffer. Fractions having lipolytic activity were collected, and fractions from $R$. miehei were applied to a MacroPrep High Q (12.6 × $40 \mathrm{~mm}$; Bio-Rad, USA), whereas fractions from Rh. oryzae to a Uno Q-1 (7 × $35 \mathrm{~mm}$; Bio-Rad, USA) anionexchange column. The columns were equilibrated with $50 \mathrm{mM}$ acetate buffer ( $\mathrm{pH}$ 6.0) and eluted with a linear gradient of $\mathrm{NaCl}$ from 0 to $1 \mathrm{M}$ at a flow rate of $1 \mathrm{ml} / \mathrm{min}$. In the case of $R$. miehei lipase, a polishing step was applied on a Sephacryl S-200 HR column (exclusion range 5 to $250 \mathrm{kDa} ; 16 \times 60 \mathrm{~mm}$; GE Healthcare, Sweden) equilibrated with $50 \mathrm{mM}$ acetate buffer ( $\mathrm{pH}$ 6.0) containing $150 \mathrm{mM} \mathrm{NaCl}$, and eluted with the same buffer at a flow rate of $0.5 \mathrm{ml} / \mathrm{min}$.

\section{Protein Determination}

During the chromatography procedures, the protein content was monitored by measuring the absorbance at $280 \mathrm{~nm}$. The total protein content in the fractions having the highest lipolytic activity was determined by using a Qubit Fluorometer (Invitrogen, USA) and the Quant-iT Protein Assay Kit (Invitrogen, USA).

\section{Protein Electrophoresis and Zymography}

Sodium dodecyl sulfate polyacrylamide gel electrophoresis (SDS-PAGE) was performed on a $4-12 \%$ NuPage Bis-Tris gel (Invitrogen, USA) according to the manufacturer's instructions. Protein bands were detected by staining the gels with $0.0025 \%$ Coomassie Brilliant Blue R-250.

For zymogram analysis, enzyme proteins were separated on 3-12\% polyacrylamide gel (native-PAGE) at $150 \mathrm{~V}$. After electrophoresis, the gels were washed with sodium phosphate buffer $(50 \mathrm{mM}, \mathrm{pH}$ 6.8) for $30 \mathrm{~min}$ at room temperature. Activity bands were developed by incubating the gels in $50 \mathrm{ml}$ of sodium phosphate buffer $(50 \mathrm{mM}$, $\mathrm{pH}$ 6.8) containing $200 \mu \mathrm{M}$ 4-methylumbelliferyl nonanoate (Sigma-Aldrich, USA), or $1 \mathrm{mM} \alpha$-naphthyl acetate (Sigma-Aldrich, USA) and $25 \mathrm{mg}$ Fast Red, at $37^{\circ} \mathrm{C}$ for $30 \mathrm{~min}$ or $2 \mathrm{~h}$, respectively.

\section{Enzyme Activity Assays}

Standard determination of lipolytic activity was performed by using $p$-nitrophenyl palmitate ( $p$ NPP; Sigma-Aldrich, USA) as the substrate. A $3 \mathrm{mM} p \mathrm{NPP}$ stock solution was prepared in dimethyl sulfoxide, and an equal volume of sodium phosphate buffer $(0.1 \mathrm{M}$, 
$\mathrm{pH}$ 6.8) was added. Unless otherwise stated, $50 \mu \mathrm{l}$ of buffered $p$ NPP solution was added to $50 \mu \mathrm{l}$ of diluted extract, and incubated for $30 \mathrm{~min}$ at $37^{\circ} \mathrm{C}$. The reaction was stopped by $25 \mu \mathrm{l}$ of $0.1 \mathrm{M}$ sodium carbonate, and the $p$-nitrophenol release was measured at $405 \mathrm{~nm}$ using an Asys Jupiter HD (ASYS Hitech, UK) microplate reader. One unit of enzyme activity was defined as the amount of enzyme that liberated $1 \mu \mathrm{M}$ of $p$-nitrophenol per minute. All enzyme activity measurements were carried out in triplicates.

Transesterification activities were studied following a standard $p$ NPP-based spectrophotometric assay described previously [13].

\section{Effects of Temperature and $\mathrm{pH}$}

The optimum temperature of the purified lipases was studied by assaying lipolytic activities in $0.1 \mathrm{M}$ sodium phosphate buffer ( $\mathrm{pH}$ 6.8) containing $0.75 \mathrm{mM} p \mathrm{NPP}$ in the range from $10^{\circ} \mathrm{C}$ to $80^{\circ} \mathrm{C}$ for $30 \mathrm{~min}$. Thermal stability was ascertained by incubating the enzyme for $4 \mathrm{~h}$ at the desired temperature, and then the residual activity was estimated at the optimal temperature of the enzymes using $0.75 \mathrm{mM} p \mathrm{NPP}$ as a substrate. The $\mathrm{pH}$ optimum of the purified lipolytic activities was determined at the appropriate optimal temperatures for $30 \mathrm{~min}$ in the range from $\mathrm{pH} 2.2$ to 8.0 by using $50 \mathrm{mM}$ Mcllvaine buffer supplemented with $0.75 \mathrm{mM} p \mathrm{NPP}$. The $\mathrm{pH}$ stability was established by pre-incubating the purified lipases in the same buffer for $24 \mathrm{~h}$ at $4^{\circ} \mathrm{C}$, and then the residual activity was evaluated by incubation for $30 \mathrm{~min}$ at the optimal temperature of the enzymes using $0.75 \mathrm{mM} p \mathrm{NPP}$ as a substrate.

\section{Enzyme Kinetics}

The apparent kinetic parameters $K_{\mathrm{m}}$ and $V_{\max }$ for the purified lipases were estimated from Lineweaver-Burk plots. The assays were carried out in sodium phosphate buffer $(0.1 \mathrm{M}, \mathrm{pH}$ 6.8) with $p$ NPP substrate in concentrations that varied from 0.05 to $3.2 \mathrm{mM}$ at $37^{\circ} \mathrm{C}$ for $30 \mathrm{~min}$.

\section{Hydrolysis of Various Aryl Esters}

Hydrolysis of aryl esters with different chain-length acids was studied by incubating the purified enzymes $(10 \mathrm{U} / \mathrm{ml})$ in $0.1 \mathrm{M}$ sodium phosphate buffer ( $\mathrm{pH}$ 6.8) containing $0.75 \mathrm{mM}$ aryl-esters ( $p \mathrm{NP}$-acetate, $p \mathrm{NP}$-propionate, $p \mathrm{NP}$-butyrate, $p \mathrm{NP}$-valerate, $p \mathrm{NP}$ caproate, $p \mathrm{NP}$-caprylate, $p \mathrm{NP}$-decanoate, $p \mathrm{NP}$-dodecanoate, and $p$ NPP; Sigma-Aldrich, USA) at the optimal temperature of the lipolytic activity for $30 \mathrm{~min}$. Then, the activities were examined by measuring the liberated $p$-nitrophenol at $405 \mathrm{~nm}$. The relative rate of hydrolysis was determined as percentages of the initial rate of hydrolysis obtained with $p$ NPP.

\section{Effects of Metal Ions and Reagents}

The effects of metal ions and chemical reagents on the lipolytic activity were assayed by incubating the purified enzymes under standard assay conditions in the presence of $5 \mathrm{mM} \mathrm{CoCl}, \mathrm{HgCl}_{2}$, $\mathrm{CuSO}_{4}, \mathrm{ZnCl}_{2}, \mathrm{MnCl}_{2}, \mathrm{CaCl}_{2}, \mathrm{MgSO}_{4}, \mathrm{NaCl}$, or $\mathrm{KCl}$, or $10 \mathrm{mM} \mathrm{N}$ bromosuccinimide (NBS), ethylenediaminetetraacetic acid (EDTA), or sodium dodecyl sulfate (SDS).

\section{Effects of Various Organic Solvents and Fatty Acids}

The effects of alkanes and alcohols on the $p$ NPP-hydrolyzing activity of the purified enzymes were studied at concentrations ranging from $5 \%$ to $20 \%(\mathrm{v} / \mathrm{v})$. The effects of fatty acids on the enzyme activity were investigated in the range from 1 to $5 \mathrm{mM}$. The $p$ NPP hydrolysis was measured at standard assay condition in the presence of solvents or fatty acids relative to the background control (without solvent or fatty acid; 100\% residual activity).

\section{Regioselectivity Studies}

Positional specificity of the purified lipases was examined through thin-layer chromatography (TLC) of the products obtained from the hydrolysis of triolein ( $99 \%$; Sigma-Aldrich, USA). The reaction medium consisted of $5 \mathrm{mg} / \mathrm{ml}$ triolein, $795 \mu \mathrm{l}$ of $0.1 \mathrm{M}$ sodium phosphate buffer ( $\mathrm{pH} 6.8$ ), and $200 \mu \mathrm{l}$ of purified enzyme solution $(10 \mathrm{U} / \mathrm{ml})$. After incubating the mixtures in an orbital shaker $(200 \mathrm{rpm})$ at $37^{\circ} \mathrm{C}$ for $2 \mathrm{~h}$, the products were extracted with diethyl ether in a volumetric ratio of 1:1. Then, a $30 \mu \mathrm{l}$ sample from the organic phase was subjected to TLC on a silica gel 60 plate (Merck, Germany) using $n$-hexane/diethyl ether/acetic acid (59:40:1 (v/v)) as a mobile phase. Triolein, oleic acid, 1,3-diolein, $( \pm)$-1,2-diolein, and monoolein were purchased from SigmaAldrich and used as reference standards. Reaction products and the standards were visualized using a saturated iodine chamber. A control reaction mixture contained $0.1 \mathrm{M}$ sodium phosphate buffer ( $\mathrm{pH}$ 6.8) instead of the enzyme solution.

\section{Results and Discussion}

\section{Purification of Lipases}

Previous studies revealed high lipolytic activities in the crude enzyme extracts of strains $R$. miehei NRRL 5282 and $R h$. oryzae NRRL 1526 cultivated in wheat bran-based solidstate medium [12]. Additionally, it has recently been proven that these extracts contain organic solvent-tolerant lipases with significant transesterification activities [13]. In this study, we successfully purified lipases from these R. miehei and Rh. oryzae crude enzyme extracts through ammonium sulfate precipitation followed by three or two steps of chromatographic separation, respectively. The purification data are summarized in Table 1 . The R. miehei and $R h$. oryzae lipases were purified 107.3- and 94.7-fold, and the recovery rate was $2.3 \%$ and $0.7 \%$, respectively. The relatively low yield can be attributed to the fractionated desalting of the proteins, which caused some activity losses during the steps, and/or the partial aggregation of the enzymes with olive oil added to the solid fermentation medium as a lipase inductor compound (see reference [12]). This lipase-lipid complex may negatively affect the enzyme purification process [14].

The molecular mass of the $R$. miehei and Rh. oryzae enzymes 
Table 1. Purification of lipases from R. miehei NRRL 5282 and Rh. oryzae NRRL 1526.

\begin{tabular}{|c|c|c|c|c|c|}
\hline & $\begin{array}{l}\text { Total protein } \\
(\mathrm{mg})\end{array}$ & $\begin{array}{l}\text { Total activity } \\
(\mu \mathrm{mol} / \mathrm{min})\end{array}$ & $\begin{array}{l}\text { Specific activity } \\
(\mathrm{U} / \mathrm{mg})\end{array}$ & $\begin{array}{l}\text { Purification } \\
\text { (fold) }\end{array}$ & $\begin{array}{c}\text { Recovery } \\
(\%)\end{array}$ \\
\hline \multicolumn{6}{|l|}{ Rhizomucor miehei NRRL 5282} \\
\hline Crude extract & $3,222.4$ & $65,489.2$ & 20.3 & 1 & 100 \\
\hline Ammonium sulfate $(75-85 \%)$ & 98.7 & $25,364.5$ & 257 & 12.7 & 38.7 \\
\hline Sephadex G-75 & 44 & 23,213 & 527.6 & 25.9 & 35.4 \\
\hline Macro-Prep HQ & 4.1 & $3,957.9$ & 970 & 47.7 & 6 \\
\hline Sephacryl S200HR & 0.7 & 1,513 & $2,181.4$ & 107.3 & 2.3 \\
\hline \multicolumn{6}{|l|}{ Rhizopus oryzae NRRL 1526} \\
\hline Crude extract & $5,662.8$ & $143,028.6$ & 25.26 & 1 & 100 \\
\hline Ammonium sulfate (50-65\%) & 102.2 & $57,865.5$ & 566.2 & 22.4 & 40.5 \\
\hline Sephadex G-75 & 11.7 & $8,147.9$ & 694.9 & 27.5 & 5.7 \\
\hline Uno Q-1 & 0.42 & 1,002 & $2,392.6$ & 94.7 & 0.7 \\
\hline
\end{tabular}

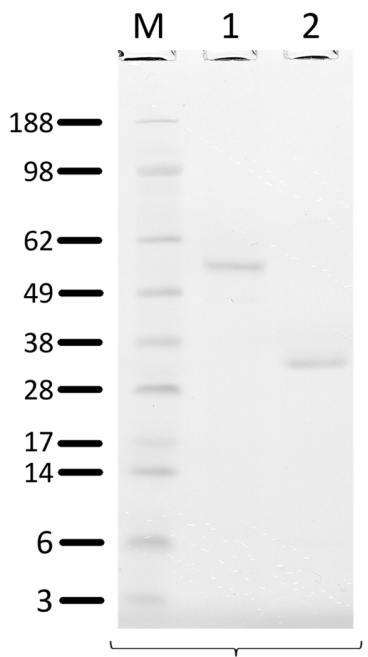

A

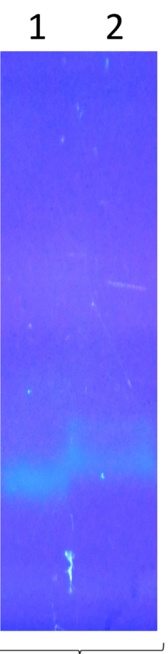

B



C
Fig. 1. SDS-PAGE (A) and zymogram (B and C) analysis of the purified lipases.

Lane 1 and lane 2 are R. miehei NRRL 5282 and Rh. oryzae NRRL 1526 lipases, respectively. Lipolytic activity staining was performed after native-PAGE by using 4-methylumbelliferyl nonanoate (B) and $\alpha$ -

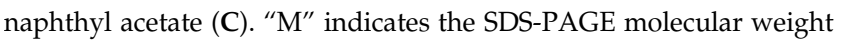
(kDa) standards (SeeBlue Plus2; Invitrogen, USA).

was estimated to be approximately 55 and $35 \mathrm{kDa}$, respectively, by SDS-PAGE (Fig. 1A). In the case of filamentous fungi, the molecular mass for lipases generally varies between 25 and $70 \mathrm{kDa}$ [10]. Biochemical properties of some Rhizomucor and Rhizopus lipases are summarized in Table 2. It shows that the molecular masses of the lipases isolated in the current study are slightly higher than those identified previously by most Rhizomucor and Rhizopus strains.

Zymogram analysis of the purified enzymes showed active lipases stained with 4-methylumbelliferyl nonanoate and $\alpha$-naphthyl acetate (Figs. 1B and 1C). Moreover, both purified enzymes catalyzed the ethyl palmitate formation from ethanol and $p N P P$ as a result of their transesterification activities. In these assays, the specific activities of 15.7 and $20.9 \mathrm{U} / \mathrm{mg}$ were detected for the R. miehei and Rh. oryzae lipases, respectively.

\section{Temperature Optimum and Stability}

The temperature optimum for maximal lipolytic activity was $40^{\circ} \mathrm{C}$ and $30^{\circ} \mathrm{C}$ for $R$. miehei and Rh. oryzae enzymes, respectively (Fig. 2). The $p$ NPP hydrolysis by R. miehei lipase decreased significantly at temperatures above $52^{\circ} \mathrm{C}$, and the enzyme exhibited only $21 \%$ of its original activity at $60^{\circ} \mathrm{C}$. However, this enzyme can be considered as thermotolerant because it retained its initial activity at $50^{\circ} \mathrm{C}$ after 4-h incubation (Fig. 2A). As mentioned above, a significant decrease in the enzymatic activity was observed above this temperature, which may be caused by the formation of aggregates instead of protein denaturation [28]. The thermal stability of many lipases, however, can be further enhanced by entrapping it to a suitable carrier [29]. Lipases with a high temperature optimum and stability have been identified and investigated from many other filamentous fungal sources [30,31]. Such lipases can be utilized in the detergent and chemical industries, including biodiesel production [1]. The Rh. oryzae lipase was less stable at temperatures above $25^{\circ} \mathrm{C}$ as compared with R. miehei enzyme (Fig. 2B). It lost about $10-15 \%$ of its activity at room temperature and was completely inactivated above $40^{\circ} \mathrm{C}$ after 4-h pre-incubation. Both enzymes were stable at $37^{\circ} \mathrm{C}$; therefore, we used this condition for further analyses. 
Table 2. Molecular mass, temperature, and pH optimum of lipases isolated from various Rhizomucor and Rhizopus strains.

\begin{tabular}{|c|c|c|c|c|}
\hline Microorganism & Molecular mass (kDa) & Temperature optimum $\left({ }^{\circ} \mathrm{C}\right)$ & pH optimum & Reference \\
\hline Rhizopus arrhizus & 67 & n.r. & n.r. & [15] \\
\hline Rhizopus chinensis & 28.4 & 37 & 5.5 & [16] \\
\hline \multicolumn{5}{|l|}{ Rhizopus chinensis } \\
\hline Lip 1 & 60 & n.r. & n.r. & [17] \\
\hline Lip 2 & 33 & 40 & $8.0-8.5$ & [18] \\
\hline \multicolumn{5}{|l|}{ Rhizopus chinensis } \\
\hline SSF lipase & 62 & 40 & 8.0 & [19] \\
\hline SmF lipase & 40 & 40 & 8.0 & \\
\hline Rhizopus delemar & 30.3 & 30 & 8.0 & [20] \\
\hline Rhizopus japonicus (NR 400) & 30 & n.r. & 5.0 & [21] \\
\hline \multicolumn{5}{|l|}{ Rhizopus niveus } \\
\hline Lipase I & 34 & 35 & $6.0-6.5$ & [22] \\
\hline Lipase II & 30 & 40 & 6.0 & \\
\hline Rhizopus oryzae & 32 & 35 & 7.5 & [23] \\
\hline Rhizopus oryzae & 17 & 40 & 7.0 & [24] \\
\hline Rhizopus oryzae WPG & 29 & 37 & 8.0 & [25] \\
\hline \multicolumn{5}{|l|}{ Rhizopus homothallicus } \\
\hline SmF lipase & 32 & 30 & 7.5 & [14] \\
\hline SSF lipase & 32 & 40 & 7.5 & \\
\hline Rhizomucor miehei & 31.6 & 37 & 8.0 & [26] \\
\hline \multicolumn{5}{|l|}{ Rhizomucor miehei (UzLT-3) } \\
\hline Lipase A & 43 & 55 & $8.7-8.8$ & [27] \\
\hline Lipase B & 40 & 45 & $8.2-8.3$ & \\
\hline Rhizopus oryzae & 35 & 30 & $6.8-7.4$ & This work \\
\hline Rhizomucor miehei & 55 & 40 & $5.0-5.4$ & This work \\
\hline
\end{tabular}

n.r.: not reported.
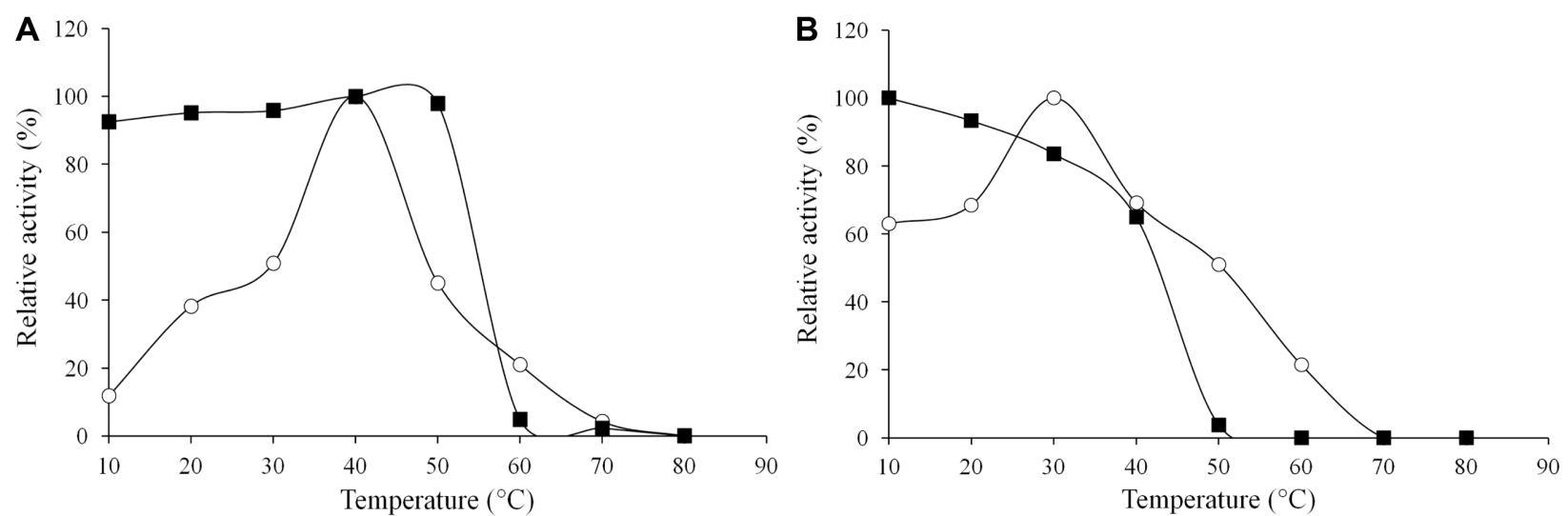

Fig. 2. Effect of temperature on the $p$ NPP-hydrolyzing activity (- $\bigcirc-)$ and stability (- - -) of purified R. miehei NRRL 5282 (A) and Rh. oryzae NRRL 1526 (B) lipases.

See Materials and Methods for experimental conditions.

\section{pH Optimum and Stability}

The purified $R$. miehei lipase had a $\mathrm{pH}$ optimum between 6.8 and 7.4 (Fig. 3A), whereas that of the Rh. oryzae enzyme was found to be between $\mathrm{pH} 5.0$ and 5.4 (Fig. 3B) after incubating at their optimal temperature conditions for $30 \mathrm{~min}$. This corresponds to the range documented for most fungal lipases [9]. Unlike the Rhizomucor lipase, the Rhizopus enzyme had a slightly wider $\mathrm{pH}$ optimum range, 

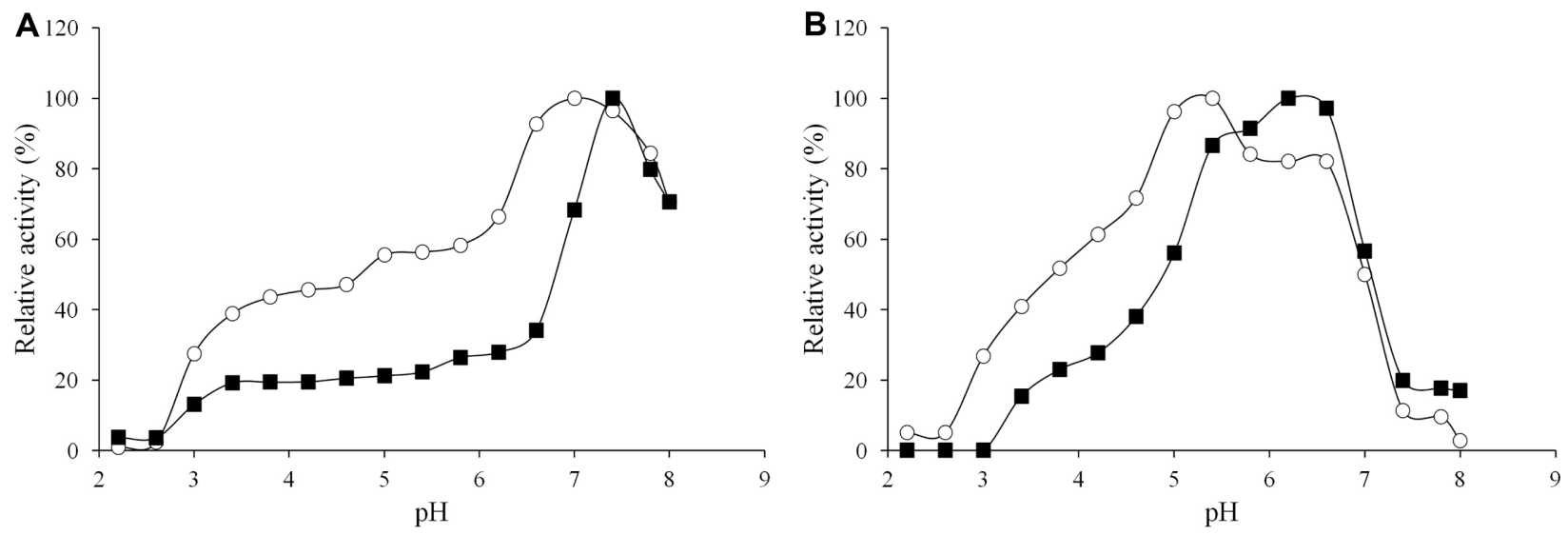

Fig. 3. Effect of $\mathrm{pH}$ on the $\mathrm{pNPP}-$ hydrolyzing activity (- - -) and stability (-口-) of purified R. miehei NRRL 5282 (A) and Rh. oryzae NRRL 1526 (B) lipases.

See Materials and Methods for experimental conditions.

presenting more than $70 \%$ residual activity from $\mathrm{pH} 4.6$ to 6.8. Fungal lipases with a $\mathrm{pH}$ optimum of about 5.0 have also been described from Aspergillus niger [31], Rhizopus japonicus NR 400 [21], and Penicillium camamberti (Amano Lipase G) isolates. Both enzymes retained about $30 \%$ of their original activity at $\mathrm{pH} 3.0$, which indicates good tolerance to acidic working conditions. One of the most common applications of acid active lipases is in the leather industry where they are used for treating the animal skins stored in a pickled state [8].

The $\mathrm{pH}$ stability of the purified lipases was also investigated by measuring the residual activity after 24-h incubation at $4^{\circ} \mathrm{C}$ at $\mathrm{pH}$ values ranging from 2.2 to 8.0. Since the $R$. miehei lipase was fairly stable and retained more than $70 \%$ of its activity in a $\mathrm{pH}$ range from 7.0 to 8.0 (Fig. 3A), it can be considered as an alkaline-tolerant enzyme. It is interesting to note that only $20-30 \%$ of its original activity was detected in the $\mathrm{pH}$ range from 3.4 to 6.2. Wu et al. [26] reported a similar $\mathrm{pH}$ stability profile for a commercial $R$. miehei lipase preparation using olive oil as a substrate. The $R h$. oryzae lipase had a wider $\mathrm{pH}$ stability range than the Rhizomucor enzyme, and retained 60-100\% of its original activity between $\mathrm{pH} 5.4$ and 6.8. However, a significant decrease in its stability could be observed after incubation in buffers above pH 7.0 (Fig. 3B). Similarly, reduced $\mathrm{pH}$ stability was detected by the lipase from $R h$. oryzae isolated from palm fruit in alkaline $\mathrm{pH}$ [23], but it was more stable under acidic conditions than the $R h$. oryzae enzyme investigated in this study. Since both tested enzymes proved to be stable at $\mathrm{pH}$ 6.8, further analyses were carried out under this condition.

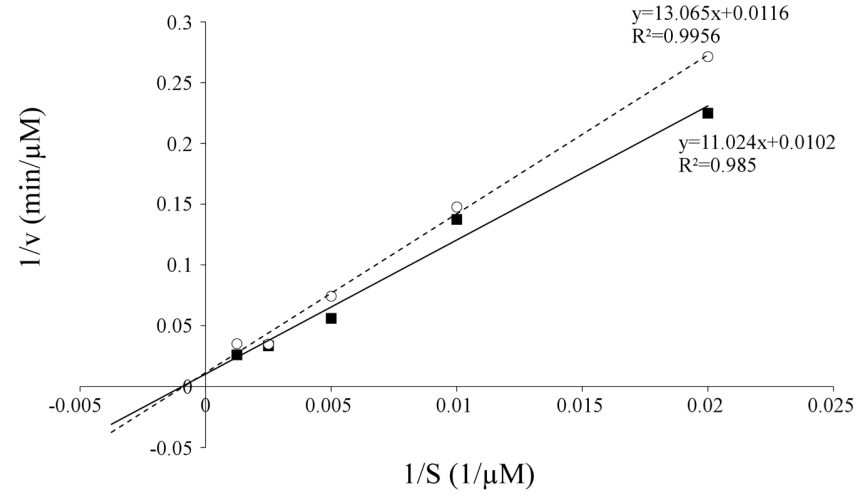

Fig. 4. Lineweaver-Burk plots for $p \mathrm{NPP}$ with the $R$. miehei NRRL 5282 (- $\bigcirc-$, dotted line) and Rh. oryzae NRRL 1526 (-口-) lipases.

\section{Kinetic Studies}

Kinetic parameters were determined from LineweaverBurk plots using different concentrations of $p$ NPP substrate. The estimated $K_{\mathrm{m}}$ and $V_{\max }$ values were $1.13 \mathrm{mM}$ and $86.2 \mu \mathrm{M} / \mathrm{min}$ for the $R$. miehei lipase, and $1.08 \mathrm{mM}$ and $98.1 \mu \mathrm{M} / \mathrm{min}$ for the $R h$. oryzae enzyme, respectively (Fig. 4). These results show that both purified enzymes have almost equal affinity to the substrate, but the $R h$. oryzae lipase-catalyzed $p$ NPP hydrolysis was about 1.13 times faster than that determined for the R. miehei enzyme. In previous studies, $p$ NPP substrate was also used to determine the kinetic parameters of different zygomycete lipases. For Mucor hiemalis f. corticola IDM11B lipase [32], $K_{\mathrm{m}}$ and $V_{\max }$ values were found to be $1.327 \mathrm{mM}$ and $91.11 \mu \mathrm{M} / \mathrm{min}$, respectively, which are very close to those obtained during 
our assays for the two enzymes. Yu et al. [33] reported $K_{\mathrm{m}}$ and $V_{\max }$ values of $0.304 \mathrm{mM}$ and $30.76 \mathrm{U} / \mathrm{mg}$, respectively, for the recombinant Rhizopus chinensis (r27RCL) lipase. These latter values indicate a more stable enzyme-substrate complex but similar $V_{\max } / K_{\mathrm{m}}$ ratio to those found for our purified R. miehei and Rh. oryzae lipases.

\section{Hydrolysis of Various Aryl Esters}

p-Nitrophenyl monoesters with C2-C16 acids were used to evaluate the chain-length specificity of the purified lipases. As can be seen in Fig. 5, both enzymes showed similar lipolysis profiles: they were most active against substrates with medium- and long-chain (C8-C16) acids, and showed low activities on short-chain (C2-C3) aryl esters. Moderate enzyme activities could be detected in the case of $p \mathrm{NP}$-butyrate (C4) and $p \mathrm{NP}$-valerate (C5). More importantly, the initial hydrolysis exhibited by the purified R. miehei enzyme was about 1.2 to 1.8 times higher on $p \mathrm{NP}$-caproate (C6), -caprylate (C8), -decanoate (C10), and -dodecanoate (C12) than that obtained on $p \mathrm{NP}$-palmitate (C16). For the Rh. oryzae enzyme, the highest activities were detected against aryl esters with $\mathrm{C} 8$ to $\mathrm{C} 12$ acids. In the case of lipases from filamentous fungi, chain-length specificity generally varies between C8 and C18 [14, 34]. Most zygomycete lipases present maximal activity for medium- or long-chain acids, but some of them have high reaction specificity for $\mathrm{C} 2$ to $\mathrm{C} 6$ acids as well $[33,35]$.

\section{Effects of Metal Ions and Reagents on Lipase Activity}

The effects of various metal ions $(5 \mathrm{mM})$ and reagents

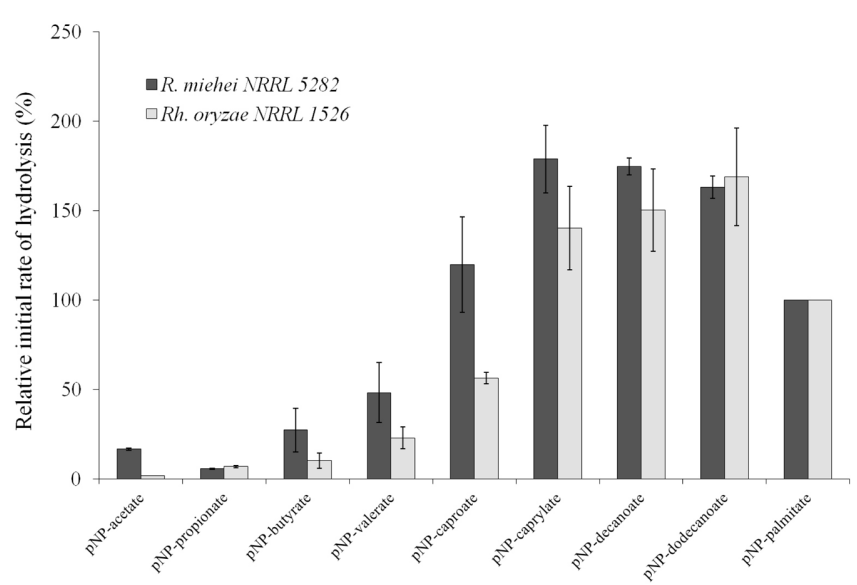

Fig. 5. Relative initial rate of hydrolysis of various aryl esters by the lipases of R. miehei NRRL 5282 and Rh. oryzae NRRL 1526.

The lipolytic activity value detected during $p$ NPP hydrolysis was considered to be $100 \%$.
(10 $\mathrm{mM})$ on $R$. miehei and $R h$. oryzae lipase activity were investigated. As shown in Table 3, significant inactivation was observed with $\mathrm{Hg}^{2+}$, NBS, and SDS. The effect of $\mathrm{Hg}^{2+}$ suggests that thiol groups are required for the adequate function of the enzyme. The inhibition effect of NBS suggests that tryptophan may be involved in the active site of the enzyme [36]. The enzyme activity was enhanced about $10 \%$ by the addition of $\mathrm{Mg}^{2+}$ to the reaction mixture; furthermore, $\mathrm{K}^{+}$had no significant effect on the enzyme activity. It was interesting to observe that, under optimal conditions $\left(40^{\circ} \mathrm{C}, \mathrm{pH} 6.8\right.$, and $\left.30 \mathrm{~min}\right), \mathrm{NPP}$ hydrolysis by R. miehei lipase was stimulated about $37 \%$ in the presence of $5 \mathrm{mM} \mathrm{Na}$. Similar stimulative effects of $\mathrm{Na}^{+}$have been described for lipases from Rhizopus oligosporus var. microsporus [37] and Geotrichum marinum [38]. Based on literature data, it can be assumed that the $\mathrm{Na}$ salt stabilizes the enzyme conformation, which enhances the enzyme activity through strengthening the integrity of the active site [39].

\section{Effects of Solvents on the Enzyme Activity}

Lipase activities are widely utilized in the organic synthesis processes, which normally require enzymes to be stable and active in most organic solvents. Such well-known application is biodiesel production, which primarily uses methanol, but other alcohols such as ethanol, isopropanol, or isobutanol are also appropriate for efficient transesterification

Table 3. Influence of metal ions and chemical reagents on the $p$ NPP-hydrolyzing activity of $R$. miehei NRRL 5282 and Rh. oryzae NRRL 1526 lipases.

\begin{tabular}{lcc}
\hline \multirow{2}{*}{ Compounds } & \multicolumn{2}{c}{ Relative activity (\%) } \\
\cline { 2 - 3 } & R. miehei & Rh. oryzae \\
\hline Control & 100 & 100 \\
$\mathrm{HgCl}_{2}$ & 10 & 12 \\
$\mathrm{CuSO}_{4}$ & 77 & 91 \\
$\mathrm{ZnCl}_{2}$ & 76 & 44 \\
$\mathrm{MnCl}_{2}$ & 60 & 63 \\
$\mathrm{CaCl}_{2}$ & 84 & 38 \\
$\mathrm{MgSO}_{4}$ & 110 & 107 \\
$\mathrm{NaCl}$ & 137 & 76 \\
$\mathrm{KCl}$ & 98 & 93 \\
$\mathrm{CoCl}$ & 79 & 80 \\
$\mathrm{NBS}$ & 18 & 8 \\
$\mathrm{EDTA}$ & 65 & 74 \\
$\mathrm{SDS}$ & 1 & 4 \\
\hline
\end{tabular}

Metal ions and reagents were used in $5 \mathrm{mM}$ and $10 \mathrm{mM}$ final concentration, respectively. Activity measured without any additive was considered to be $100 \%$. 

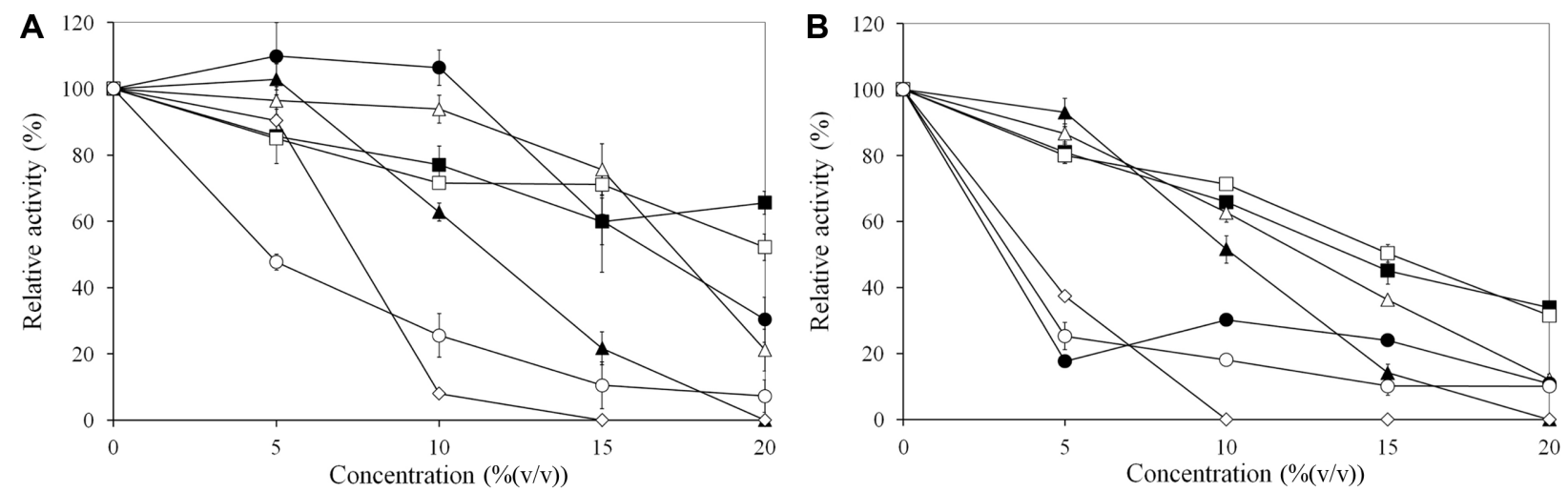

Fig. 6. Effects of alcohols (- $\square$ - methanol, - $\square$ - ethanol, - $\Delta$ - propanol, - $\triangle$ - isopropanol, - $\diamond$ - butanol, - - - isopentanol, - $\bigcirc$ - hexanol) on the $p$ NPP-hydrolyzing activity of lipases from R. miehei NRRL 5282 (A) and Rh. oryzae NRRL 1526 (B).

Values are the average of assays performed in triplicates; error bars represent the standard deviation.

of fatty acids [40]. Here, we investigated the lipolytic activity of the purified $R$. miehei and Rh. oryzae lipases in the presence of various primary and secondary alcohols and alkanes. Fig. 6 shows that the activities of both enzymes decreased in the presence of $5-10 \%(\mathrm{v} / \mathrm{v})$ hexanol and butanol, and low concentrations of methanol, ethanol, propanol, and isopropanol had no considerable effect on the $p$ NPP hydrolysis. The Rh. oryzae enzyme proved to be sensitive for the presence of isopentanol as well (Fig. 6B). However, interestingly, a slight increase in the $p \mathrm{NPP}$ hydrolysis could be observed by the $R$. miehei lipase at up to $10 \%(\mathrm{v} / \mathrm{v})$ of isopentanol (Fig. 6A). Overall, the enzymes were more stable in methanol and ethanol at higher concentrations $(20 \%(\mathrm{v} / \mathrm{v}))$ than the other alcohols tested, which is similar to that documented for the lipase from M. hiemalis f. corticola IDM11B [32]. Both enzymes retained their initial activity at high concentrations of $n$-hexane, cyclohexane, $n$-heptane, and isooctane (Fig. 7). In a similar study, a $R$ h. oryzae strain isolated from palm fruit was also stable in alkanes, but it denatured in the presence of shortchain alcohols [23]. The changes in the enzyme activity due to the effect of various organic solvents can be attributed to the influences of various factors, such as the chemical structure of the solvent, its physical parameters, and the overall structure of the enzyme [41].

\section{Effects of Fatty Acids on the Activity}

Lipases produce free fatty acids that have different effects on the original enzyme activity: they may act as a competitive inhibitor or can stimulate the initial activity in low concentrations [42, 43]. Although lipase-catalyzed esterification and modification of various free fatty acids have extensively been investigated in the literature, as we know, the effect of these compounds on the hydrolytic
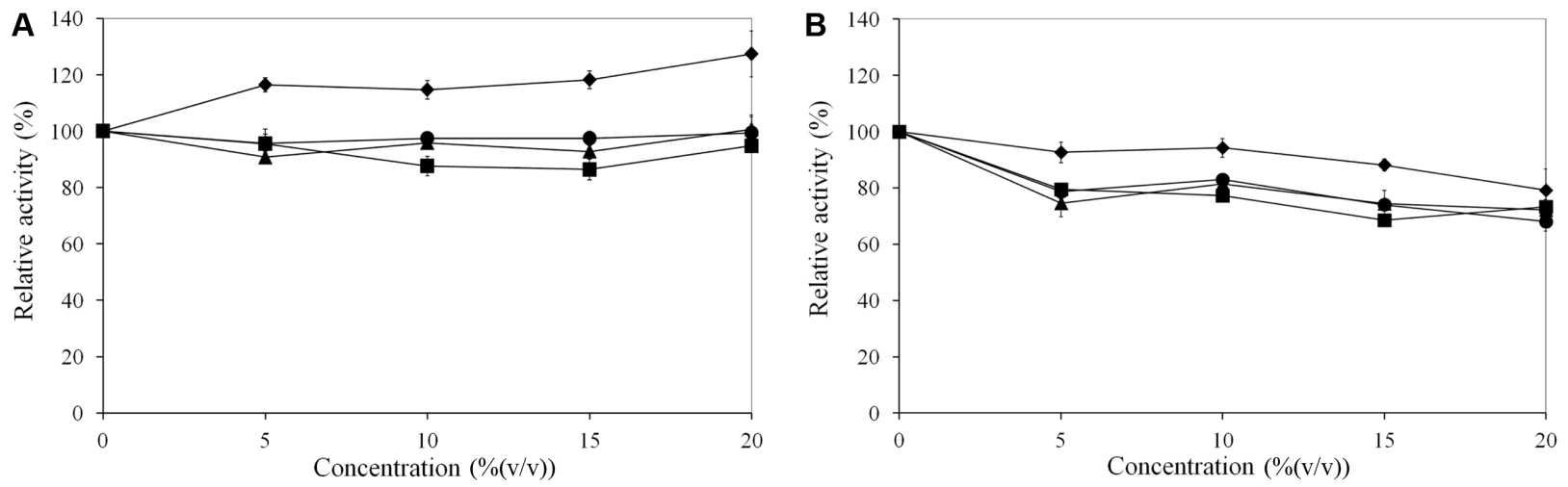

Fig. 7. Effects of alkanes (- $\mathbf{-}-n$-hexane, - $\mathbf{\Delta}$ - cyclohexane, n-heptane, - isooctane) on the $p$ NPP-hydrolyzing activity of lipases from $R$. miehei NRRL 5282 (A) and Rh. oryzae NRRL 1526 (B).

Values are the average of assays performed in triplicates; error bars represent the standard deviation. 

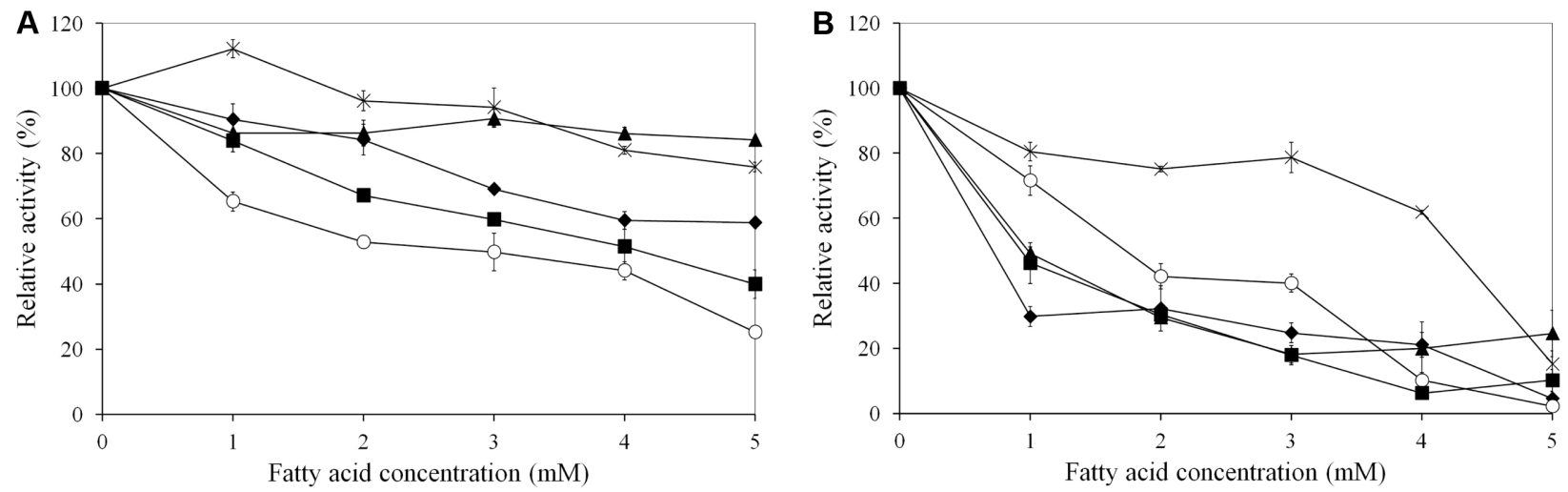

Fig. 8. Effects of fatty acids (-x-propionic acid, - - - myristic acid, - $\bigcirc$ - palmitic acid, - $\Delta$ - stearic acid, - $\mathbf{-}$ - linoleic acid) on R. miehei NRRL 5282 (A) and Rh. oryzae NRRL 1526 (B) lipases.

Values are averages calculated from the data of three independent measurements; error bars indicate the standard deviations.

activity of $R$. miehei and Rh. oryzae lipases was still unknown. Here, we have examined the fatty acid tolerance of the purified R. miehei NRRL 5282 and Rh. oryzae NRRL 1526 lipases in the presence of propionic (C3), myristic (C14), palmitic (C16), stearic (C18), and linoleic (C18:2) acids in concentrations ranging from 1 to $5 \mathrm{mM}$. Relative activity data in Fig. 8 show the effect of fatty acid concentrations on the $p$ NPP hydrolysis. Overall, the long-chain fatty acids generally decreased the enzyme activities in a dosedependent manner. These fatty acids are closer to the optimal substrate of both enzymes (see Fig. 5), which suggests a competition with the $p$ NPP substrate for the active site. However, the $R$. miehei enzyme showed moderate activation $(112 \%$ of the initial activity) at $1 \mathrm{mM}$ propionic acid (Fig. 8A). As reported for other microbial lipases [43], this activation raises a specific or cooperative binding of the fatty acid to the protein surface. The $R h$. oryzae lipase was more sensitive to all fatty acids than the $R$. miehei enzyme. Propionic acid exhibited the lowest inhibitory effect towards the Rh. oryzae lipase too (Fig. $8 \mathrm{~B}$ ), which also proves the above suggestions. Interestingly, the R. miehei enzyme showed a moderate inhibition in the presence of $5 \mathrm{mM}$ stearic acid, the longest carbon chain fatty acid involved in the analysis (Fig. 8A). Although these results cannot be extrapolated directly from one enzyme to another, they would also provide useful data for industries that utilize Rhizomucor and Rhizopus commercial lipases as biocatalysts.

\section{Regioselectivity}

Positional specificity during the hydrolysis of triacylglycerol is an important practical feature of lipases. It influences not only the nature of diglycerides formed as a result of the hydrolysis but also reflects the potential use of the enzyme for the catalysis of unique esterification reactions. According to their preference for acyl groups on the triacylglycerol, lipases can be categorized as 1,3-specific, 2-specific, and nonspecific. This property can be investigated by TLC of the products formed after the enzymatic hydrolysis of triolein substrate. Fig. 9 shows the mode of reaction of the purified Rh. oryzae (lane 7) and R. miehei (lane 8) lipases. After $2 \mathrm{~h}$ of incubation, both enzymes cleaved only the 1and 3-positioned ester bonds, since the obtained products were oleic acid, ( \pm )-1,2- diglyceride, and monoolein. 1,3Diglyceride was not seen; thus, they do not act on the 2positioned ester bond of triacylglycerols. This kind of position-specific property has been documented for some fungal lipases, such as enzymes from Rhizopus oryzae ATCC 96382 and Rh. rhizopodiformis [44], Aspergillus oryzae and A. niger NCIM 1207 [45, 46], and for many other bacterial enzymes [47-49]. It is also known that the 1- or 3regioselectivity is typical of several lipases that can catalyze transesterification reactions with high conversion yield $[50,51]$. The enzymes investigated in our study also possess such synthetic activities (see the above section "Purification of Lipases" and [13]).

This study reported the purification and biochemical characterization of $R$. miehei NRRL 5282 and Rh. oryzae NRRL 1526 lipases from crude enzyme extracts, which exhibited high esterification and transesterification activities [13]. The purified enzymes had a molecular mass of 55 and $35 \mathrm{kDa}$ on SDS-PAGE, respectively, and catalyzed transesterification in organic solvents. The Rhizomucor enzyme presented maximal $p$ NPP hydrolysis at $40^{\circ} \mathrm{C}$ and $\mathrm{pH} 5.2$, whereas these features proved to be $30^{\circ} \mathrm{C}$ and $\mathrm{pH}$ 7.0 for the Rhizopus lipase. The R. miehei enzyme had short-term stability at $50^{\circ} \mathrm{C}$, and it remained active in the 


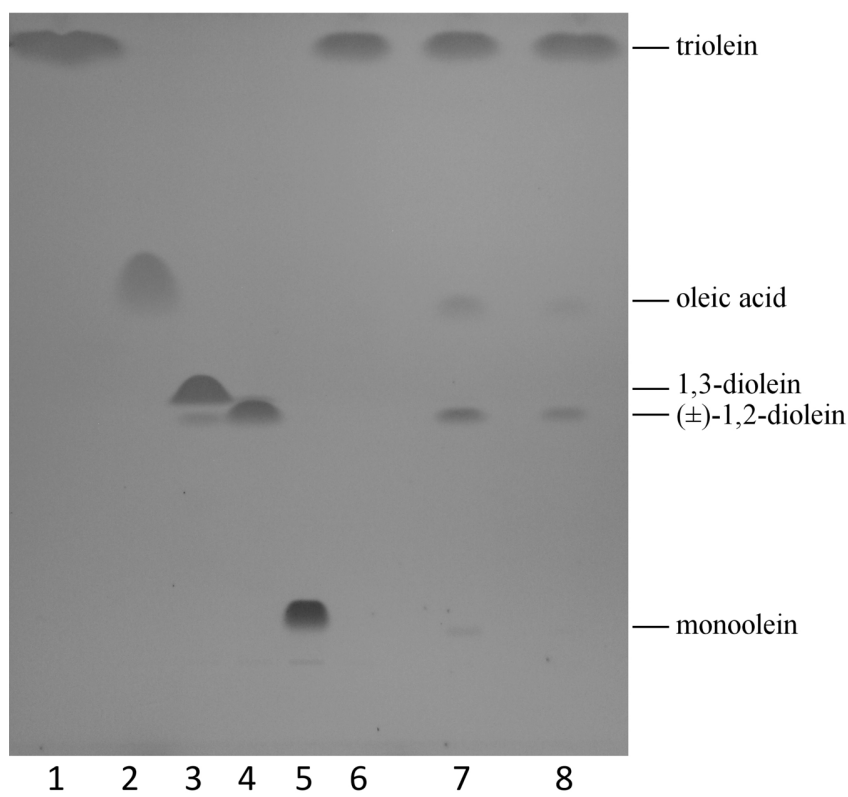

Fig. 9. Regioselectivity of the lipases from Rh. oryzae NRRL 1526 and R. miehei NRRL 5282.

Lane 1: triolein; Lane 2: oleic acid; Lane 3: 1,3-diolein; Lane 4: ( \pm )-1,2diolein; Lane 5: monoolein; Lane 6: control (without addition of enzyme); Lane 7: hydrolysis products by Rh. oryzae NRRL 1526; Lane 8: hydrolysis products by R. miehei NRRL 5282. The lower spot in lane 3 may be impurity.

presence of a low concentration of free fatty acids; moreover, $1 \mathrm{mM}$ propionic acid positively affected the $p$ NPP hydrolysis. Both purified lipases displayed high affinity to the $p$ NPP substrate, wide substrate specificity (C8-C16 acids), 1,3-positional specificity, and stability in most common solvents used for enzymatic reactions in organic media. These results suggest that $R$. miehei NRRL 5282 and Rh. oryzae NRRL 1526 lipases possess properties that can be valuable for future industrial applications.

\section{Acknowledgments}

This work was supported by the NKFIH grants PD 112234, NN 106394 and connected to the projects GINOP2.3.3-15-2016-00006 and TÉT_12_SK-1-2013-0007. The authors extend their sincere appreciations to the Deanship of Scientific Research at King Saud University for its funding of this Prolific Research Group (PRG-1437-36). TP is granted by the HAS "Momentum" project LP2016-8/2016.

\section{References}

1. Jaeger KE, Reetz MT. 1998. Microbial lipases form versatile tools for biotechnology. Trends Biotechnol. 16: 396-403.

2. Kazlauskas RJ, Bornscheuer UT. 1998. Biotransformations with lipases, pp. 37-191. In Rehm HJ, Reed G (eds.). Biotechnology: Biotransformations I, 2nd Ed., Vol. 8a. WileyVCH Verlag $\mathrm{GmbH}$, Weinheim

3. Verma ML, Azmi W, Kanwar SS. 2008. Microbial lipases: at the interface of aqueous and non-aqueous media. Acta Microbiol. Immunol. Hung. 55: 265-294.

4. Masse L, Kennedy KJ, Chou SP. 2001. The effect of an enzymatic pretreatment on the hydrolysis and size reduction of fat particles in slaughterhouse wastewater. J. Chem. Technol. Biotechnol. 76: 629-635.

5. Takamoto T, Shirasaka H, Uyama H, Kobayashi S. 2001. Lipase-catalyzed hydrolytic degradation of polyurethane in organic solvent. Chem. Lett. 30: 492-493.

6. Ferreira JA, Lennartsson PR, Edebo L, Taherzadeh MJ. 2013. Zygomycetes-based biorefinery: present status and future prospects. Bioresour. Technol. 135: 523-532.

7. Papp T, Nyilasi I, Csernetics Á, Nagy G, Takó M, Vágvölgyi C. 2016. Improvement of industrially relevant biological activities in Mucoromycotina fungi, pp. 97-118. In Schmoll M, Dattenböck C (eds.). Gene Expression Systems in Fungi: Advancements and Applications. Fungal Biology Series. Springer International Publishing, Switzerland.

8. Hasan F, Shah AA, Hameed A. 2006. Industrial applications of microbial lipases. Enzyme Microb. Technol. 39: 235-251.

9. Sharma D, Sharma B, Shukla AK. 2011. Biotechnological approach of microbial lipase: a review. Biotechnology 10: 23-40.

10. Singh AK, Mukhopadhyay M. 2012. Overview of fungal lipase: a review. Appl. Biochem. Biotechnol. 166: 486-520.

11. Rodrigues RC, Fernandez-Lafuente R. 2010. Lipase from Rhizomucor miehei as an industrial biocatalyst in chemical process. J. Mol. Catal. B Enzym. 64: 1-22.

12. Kotogán A, Németh B, Vágvölgyi C, Papp T, Takó M. 2014. Screening for extracellular lipase enzymes with transesterification capacity in Mucoromycotina strains. Food Technol. Biotechnol. 52: 73-82.

13. Kotogán A, Kecskeméti A, Szekeres A, Papp T, Chandrasekaran M, Kadaikunnan S, et al. 2016. Characterization of transesterification reactions by Mucoromycotina lipases in non-aqueous media. J. Mol. Catal. B Enzym. 127: 47-55.

14. Mateos Diaz JC, Rodríguez JA, Roussos S, Cordova J, Abousalham A, Carriere F, Baratti J. 2006. Lipase from the thermotolerant fungus Rhizopus homothallicus is more thermostable when produced using solid state fermentation than liquid fermentation procedures. Enzyme Microb. Technol. 39: 1042-1050.

15. Chattopadhyay M, Banik AK, Raychaudhuri S. 1999. Production and purification of lipase by a mutant strain of Rhizopus arrhizus. Folia Microbiol. 44: 37-40.

16. Yasuda M, Ogino H, Kiguchi T, Kotani T, Takakura S, Ishibashi T, et al. 1999. Purification and characterization of lipase from Rhizopus chinensis cells. J. Biosci. Bioeng. 88: 571- 
573.

17. Sun SY, Xu Y. 2008. Solid-state fermentation for 'whole-cell synthetic lipase' production from Rhizopus chinensis and identification of the functional enzyme. Process Biochem. 43: 219-224.

18. Sun SY, Xu Y, Wang D. 2009. Novel minor lipase from Rhizopus chinensis during solid-state fermentation: biochemical characterization and its esterification potential for ester synthesis. Bioresour. Technol. 100: 2607-2612.

19. Sun SY, Xu Y. 2009. Membrane-bound 'synthetic lipase' specifically cultured under solid-state fermentation and submerged fermentation by Rhizopus chinensis: a comparative investigation. Bioresour. Technol. 100: 1336-1342.

20. Haas MJ, Cichowicz DJ, Bailey DG. 1992. Purification and characterization of an extracellular lipase from the fungus Rhizopus delemar. Lipids 27: 571-576.

21. Suzuki M, Yamamoto H, Mizugaki M. 1986. Purification and general properties of a metal-insensitive lipase from Rhizopus japonicus NR 400. J. Biochem. 100: 1207-1213.

22. Kohno M, Kugimiya W, Hashimoto Y, Morita Y. 1994. Purification, characterization and crystallization of two types of lipases from Rhizpous niveus. Biosci. Biotechnol. Biochem. 58: 1007-1012.

23. Hiol A, Jonzo MD, Rugani N, Druet D, Sarda L, Comeau LC. 2000. Purification and characterization of an extracellular lipase from a thermophilic Rhizopus oryzae strain isolated from palm fruit. Enzyme Microb. Technol. 26: 421-430.

24. Kantak JB, Prabhune AA. 2012. Characterization of smallest active monomeric lipase from novel Rhizopus strain: application in transesterification. Appl. Biochem. Biotechnol. 166: $1769-1780$.

25. Ben Salah R, Mosbah H, Fendri A, Gargouri A, Gargouri Y, Mejdoub H. 2006. Biochemical and molecular characterization of a lipase produced by Rhizopus oryzae. FEMS Microbiol. Lett. 260: 241-248.

26. Wu XY, Jääskeläinen S, Linko YY. 1996. Purification and partial characterization of Rhizomucor miehei lipase for ester synthesis. Appl. Biochem. Biotechnol. 59: 145-158.

27. Gulyamova KA, Davranov KD. 1995. Properties of two lipases from the fungus Mucor miehei. Chem. Nat. Compd. 31: 372-375.

28. Noel M, Combes D. 2003. Effects of temperature and pressure on Rhizomucor miehei lipase stability. J. Biotechnol. 102: 23-32.

29. Reetz MT, Zonta A, Simpelkamp J. 1996. Efficient immobilization of lipases by entrapment in hydrophobic sol-gel materials. Biotechnol. Bioeng. 49: 527-534.

30. Monteiro JB, Nascimento MG, Ninow JL. 2003. Lipasecatalyzed synthesis of monoacylglycerol in a homogeneous system. Biotechnol. Lett. 25: 641-644.

31. Namboodiri VM, Chattopadhyaya R. 2000. Purification and biochemical characterization of a novel thermostable lipase from Aspergillus niger. Lipids 35: 495-502.
32. Ülker S, Karaoğlu ŞA. 2012. Purification and characterization of an extracellular lipase from Mucor hiemalis f. corticola isolated from soil. J. Biosci. Bioeng. 114: 385-390.

33. Yu XW, Wang LL, Xu Y. 2009. Rhizopus chinensis lipase: gene cloning, expression in Pichia pastoris and properties. J. Mol. Catal. B Enzym. 57: 304-311.

34. Saxena RK, Agarwal L, Meghwanshi GK. 2005. Diversity of fungal and yeast lipases: present and future scenario for the 21st century, pp. 791-814. In Satyanarayana T, Johri BN (eds.). Microbial Diversity: Current Perspectives and Potential Applications. I. K. International Publishing House Pvt Ltd, New Delhi.

35. Hiol A, Jonzo MD, Druet D, Comeau L. 1999. Production, purification and characterization of an extracellular lipase from Mucor hiemalis f. hiemalis. Enzyme Microb. Technol. 25: 80-87.

36. Koblitz MGB, Pastore GM. 2006. Purification and biochemical characterization of an extracellular lipase produced by a new strain of Rhizopus sp. Ciênc. Agrotec. 30: 494-502.

37. Iftikhar T, Niaz M, Jabeen R, Haq IU. 2011. Purification and characterization of extracellular lipases. Pak. J. Bot. 43: 15411545.

38. Huang Y, Locy R, Weete JD. 2004. Purification and characterization of an extracellular lipase from Geotrichum marinum. Lipids 39: 251-257.

39. Noel M, Combes D. 2003. Rhizomucor miehei lipase: differential scanning calorimetry and pressure/temperature stability studies in presence of soluble additives. Enzyme Microb. Technol. 33: 299-308.

40. Salis A, Monduzzi M, Solinas V. 2007. Use of lipases for the production of biodiesel, pp. 317-339. In Polaina J, Maccabe AP (eds.). Industrial Enzymes. Structure, Function and Applications. Springer Netherlands, Dordrecht.

41. Li Z, Li X, Wang Y, Wang Y, Wang F, Jiang J. 2011. Expression and characterization of recombinant Rhizopus oryzae lipase for enzymatic biodiesel production. Bioresour. Technol. 102: 9810-9813.

42. Markweg-Hanke M, Lang S, Wagner F. 1995. Dodecanoic acid inhibition of a lipase from Acinetobacter sp. OPA 55. Enzyme Microb. Technol. 17: 512-516.

43. Ruiz C, Falcocchio S, Xoxi E, Pastor FJ, Diaz P, Saso L. 2004. Activation and inhibition of Candida rugosa and Bacillusrelated lipases by saturated fatty acids, evaluated by a new colorimetric microassay. Biochim. Biophys. Acta 1672: 184-191.

44. Razak CN, Salleh AB, Musani R, Samad MY, Basri M. 1997. Some characteristics of lipases from thermophilic fungi isolated from palm oil mill effluent. J. Mol. Catal. B Enzym. 3: 153-159.

45. Toida J, Arikawa Y, Kondou K, Fukuzawa M, Sekiguchi J. 1998. Purification and characterization of triacylglycerol lipase from Aspergillus oryzae. Biosci. Biotechnol. Biochem. 62: 759-763.

46. Mhetras NC, Bastawde KB, Gokhale DV. 2009. Purification 
and characterization of acidic lipase from Aspergillus niger NCIM 1207. Bioresour. Technol. 100: 1486-1490.

47. Bakir ZB, Metin K. 2016. Purification and characterization of an alkali-thermostable lipase from thermophilic Anoxybacillus flavithermus HBB 134. J. Microbiol. Biotechnol. 26: 1087-1097.

48. Ebrahimpour A, Rahman RN, Basri M, Salleh AB. 2011. High level expression and characterization of a novel thermostable, organic solvent tolerant, 1,3-regioselective lipase from Geobacillus sp. strain ARM. Bioresour. Technol. 102: 6972-6981.

49. Lotrakul P, Dharmsthiti S. 1997. Purification and characterization of lipase from Aeromonas sobria LP004. J. Biotechnol. 54: 113-120.

50. Alnoch RC, Martini VP, Glogauer A, dos Santos Costa AC, Piovan L, Muller-Santos M, et al. 2015. Immobilization and characterization of a new regioselective and enantioselective lipase obtained from a metagenomic library. PLoS One 10: e0114945.

51. Yücel S, Terzioğlu P, Özçimen D. 2012. Lipase applications in biodiesel production, pp. 209-250. In Fang Z (ed.). Biodiesel - Feedstocks, Production and Applications. InTech, Croatia. 